\title{
Efficacy of Disinfectants against Health-Associated Multi-drug Resistant Clinical Isolates
}

\author{
Jeong-Lib An ${ }^{1, *}$, Sang-Ha Kim ${ }^{2, *}$, Young-Bin $\mathrm{Yu}^{3, *}$, Sunghyun Kim${ }^{4, *}$, \\ Moo-Sik Lee ${ }^{5, \dagger ; *}$ and Young-Kwon Kim ${ }^{6, \dagger ; *}$ \\ ${ }^{I}$ Department of Health Sciences, The Graduate School of Konyang University, Daejeon 35365, Korea \\ ${ }^{2}$ Department of Laboratory Medicine, Konyang University Hospital, Daejeon 35365, Korea \\ ${ }^{3}$ Department of Biomedical Laboratory Science, College of Medical Sciences, \\ Konyang University, Daejeon 35365, Korea \\ ${ }^{4}$ Department of Clinical Laboratory Sciences, College of Health Sciences, \\ Catholic University of Pusan, Busan 46252, Korea \\ ${ }^{5}$ Department of Medicine, College of Medicine, Konyang University, Daejeon 35365, Korea \\ ${ }^{6}$ Department of Health Sciences, The Graduate School of Konyang University, Daejeon 35365, Korea
}

The purpose of this study was to evaluate the disinfecting efficacy of peracetic acid (PAA), sodium hypochlorite $(\mathrm{NaOCl})$ and phenol, which are representative disinfectants in medical environments using four types of multi-drug resistance (MDR) clinical isolates with healthcare-associated infections (HAI). 26 antibiotic susceptibility tests were conducted for the four types of MDR clinical isolates in the same way as for clinical specimens. The minimum inhibitory concentration (MIC) and the minimum bactericidal concentration (MBC) of the disinfectants were determined by using in vitro liquid medium dilution method and inoculation of the plate medium. Both the MIC and $\mathrm{MBC}$ of phenol against MRSA and VRE were 3.1\%, while those against KPC and MRPA were $6.2 \%$. The MIC and MBC of peracetic acid (PAA) against MRSA, VRE, KPC, and MRPA were $0.18 \%$. The MIC and MBC of sodium hypochlorite (NaOCl) against MRSA were $0.39 \%$ and $0.78 \%$, respectively. Both values of MIC and MBC were $0.78 \%$ for VRE. In addition, KPC and MRPA showed $0.39 \%$ for MIC and $0.78 \%$ for MBC. For all MDR strains used in this study, sodium hypochlorite and peracetic acid showed significant sterilizing efficiency, while no clear correlation was identified between antibiotic resistance clinical isolated and ability of disinfection.

Key Words: Minimum Inhibition Concentration (MIC), Multi-drug Resistance clinical isolates, Peracetic acid (PAA), Phenol, Sodium hypochlorite

\footnotetext{
Received: September 27, 2021 / Revised: November 15, 2021 / Accepted: November 16, 2021

* Professor.

${ }^{\dagger}$ Corresponding author: Moo-Sik Lee. Department of Medicine, College of Medicine, Konyang University, 158 Gwanjeodong-ro, Seo-gu, Daejeon 35365, Korea.

Tel: 82-10-2514-4527, Fax: 82-42-600-8631, e-mail: mslee@konyang.ac.kr

${ }^{\dagger}$ Corresponding author: Young-Kwon Kim. Department of Health Sciences, The Graduate School of Konyang University, 158 Gwanjeodong-ro, Seo-gu, Daejeon 35365, Korea.

Tel: 82-10-6436-3245, Fax: 82-42-600-6401, e-mail: ykkim3245@konyang.ac.kr

(C) The Korean Society for Biomedical Laboratory Sciences. All rights reserved.

(C) This is an Open Access article distributed under the terms of the Creative Commons Attribution Non-Commercial License (http://creativecommons.org/licenses/by-nc/3.0/) which permits unrestricted non-commercial use, distribution, and reproduction in any medium, provided the original work is properly cited.
} 


\section{서 론}

최근 들어 코로나바이러스-19 감염증(Corona Virus Disease 19, COVID-19)의 세계적 유행, 중증급성 호흡기감염증 바이러스 감염증(severe acute respiratory syndrome coronavirus, SARS-CoV), 중동 호흡기감염증 바이러스 감염증 (middle east respiratory syndrome coronavirus, MERS-CoV) 와 신종인플루엔자 감염증(Influenzavirus H1N1), 에볼라바 이러스 감염증(Ebola virus disease), 지카바이러스 감염증 (Zikavirus disease), 의료관련 감염 내성균 감염(HealthcareAssociated Multi-drug Resistance Bacteria) 등 세계 도처에서 다양한 새로운 병원체로 인한 신종 출현 감염병(Emerging infectious disease)의 증가와 감염경로의 다양화로 인해 질 병의 양상도 다양하게 변화하고 있어 감염병의 예방과 피 해 확산을 방지하려는 노력이 증가하고 있다(Chung, 2018).

특히 의료관련 감염을 일으키는 미생물들은 주로 직간 접적인 접촉으로 인해 공기나 비말을 통해서 전파되기도 하며, 오염된 물이나 식품, 투약 및 의료 처치 및 의료 환 경 등을 통해서 전파되는 경우도 있다. 일부 환자에서 증 상을 동반하는 감염이 발생하는 경우도 있으나, 대부분 환자에서는 증상 없이 세균을 보유하고 있는 집락화 상 태로 나타나기도 한다. 그러나 환자가 무증상 보균자인 경우에도 주변 환경을 오염시킬 수 있기 때문에 무증상 보균자도 항생제내성 세균의 전파에 중요한 요인으로 작 용하며, 의료관련 감염은 전 세계적으로 이환율과 사망률 의 중요한 원인이 된다(Guimarães et al., 2000).

의료 환경의 소독방법은 병원성 또는 잠재적 병원성 미생물로 인한 감염증을 예방하거나 감소시키는 것을 목 표로 한다. HAIs (healthcare-associated infections)은 전 세계 적으로 이환율과 사망률의 중요한 원인을 나타내기 때문 에 의료 환경 표면의 오염은 공중보건학적으로 매우 중 요한 문제가 되고 있다(Quinn et al., 2015).

살균소독제의 살균효과는 소독제가 미생물과 접촉하는 시간과 소독제의 농도, 살균소독제를 사용할 때의 온도 의 변화와 $\mathrm{pH}$, 유기물질의 존재 여부, 미생물의 종류 등 에 의해 영향을 받는다. 따라서 의료기관 및 공공장소에 서의 환경 특성을 고려한 효과적인 살균소독제를 선택 하여 사용하여야 미생물 증식과 감염발생을 예방할 수 있기 때문에 의료시설에서 적용할 소독제의 시험관 내(in vitro) 항균 활성을 조사하는 것은 소독제와 소독방법 선 택에 중요한 의미가 있다(Lee et al., 2005).
본 실험에 사용한 소독제 중 하나인 과초산(Peracetic acid, $\left.\mathrm{PAA}), \mathrm{C}_{2} \mathrm{H}_{4} \mathrm{O}_{3}\right)$ 은 물에 녹아있는 초산 $\left(\mathrm{CH}_{3} \mathrm{COOH}\right)$ 과 과산화수소 $\left(\mathrm{H}_{2} \mathrm{O}_{2}\right)$ 의 혼합물로 환경 표면 살균제로 작용 하며 다른 산화제와 유사하게 작용하여 세포벽 투과과정 을 파괴하고 단백질, 효소 및 기타 대사산물의 황화결합 을 산화시켜 사멸한다(Malchesky, 1993).

차아염소산나트륨(Sodium hypochlorite, $\mathrm{NaOCl}$ )은 미생 물의 단백질 세포활성을 파괴하며, 뉴클레오티드 염기의 염소화 유도체의 형성을 통해 미생물의 DNA에 유해한 영향을 미치기 때문에 세균, 바이러스 및 곰팡이의 소독 에 효과적이며, 경제적으로도 저렴하여 수질정화에 효과 적으로 사용될 수 있는 화합물이다. 대조 소독제로 다른 소독제의 효력을 비교할 때의 기준으로 되고 있는 페놀 (phenol)을 사용하였다(Maria et al., 2018).

의료관련 감염 임상 분리균주에 대한 항생제 내성에 대해서는 광범위하게 연구되고 있지만, 의료관련 감염 다제 내성균에 대한 소독작용과의 연관성에 관한 연구 는 소수에 불과하며, 국내에서의 연구는 거의 없는 실 정이다.

따라서 본 연구에서는 임상의 환자에서 의료관련 감염 다제 내성균 4종 MRSA, VRE, MRPA, $\mathrm{KPC}$ 를 대상으로 병원 의료환경 소독제로 사용하고 있는 대표적인 소독제 인 과초산(peracetic acid, PAA), 차아염소산 나트륨(sodium hypochlorite, $\mathrm{NaOCl})$, 및 페놀(phenol)에 대한 소독력을 평 가하여 의료 환경의 감염관리를 위한 소독제의 선택에 참고할 기초 자료를 제공하고자 하였다.

\section{재료 및 방법}

\section{세균의 분리 및 동정}

대전 시내 $\mathrm{K}$ 대학병원의 임상검체에서 분리된 세균 중 Gram 염색과 1차 배양을 시행하여 Gram 양성세균 및 Gram 음성세균을 분리하였고, VITEK II compact (Biomerieux Durham NC, USA) 자동화 동정 시스템으로 동정 하였으며, 의료관련 감염 항생제 내성세균 4 종을 분리하 였다.

\section{실험에 사용한 소독제}

실험에 사용한 소독제는 시중에 판매되는 용액의 원액 을 제조업체의 지침에 따라 희석하여 사용하였다.

1) 차아염소산나트륨(Sodium hypochlorite), 6 14\% available chlorine, SAMCHUN PURE CHEMICAL CO. LTD. Korea 
2) 과초산(Peraetic acid), 1.5\% solution trade name Peragreen Nexchem, CO, Korea

3) 페놀(Phenol), A, $>98.0 \%$ trade name Bisphenol SAMCHUN PURE CHEMICAL CO. LTD. Korea

\section{배지 및 시약}

고압 멸균된 trypticase soy broth (TSB, Oxoid, UK), trypticase soy agar (TSA, Oxoid, UK)와 혈액우무배지(sheep blood agar plate, Oxoid, UK)를 사용하였다. 시험관 $(25 \times 150 \mathrm{~mm})$, 항온수조 $\left(56^{\circ} \mathrm{C}\right.$ JeioTech CO, Korea), 항온기 $\left(37^{\circ} \mathrm{C}\right.$ JeioTech $\mathrm{CO}$, Korea), 배양기 $\left(25 \sim 30^{\circ} \mathrm{C}\right.$ JeioTech CO, Korea), 페트리 디쉬, 현미경, 생리식염수 등을 사용하였다.

\section{소독제의 최소발육억제농도(minimum inhibitory concen- tration, MIC) 측정}

약제의 미생물 발육을 억제하는 최소농도를 측정하기 위해 시험관희석법을 사용하였다. 소독제의 농도가 $1 / 2$ 배 희석계열이 되도록 제작한 $\mathrm{TSB}$ 배지에 시험균을 $1 \mathrm{~mL}$ 씩 접종한 후 이를 $37^{\circ} \mathrm{C}$ 배양기에서 24시간 배양하여 접 종한 시험 세균의 발육 유무를 육안으로 확인하여 최소 발육억제농도를 판정하였다.

\section{소독제의 최소살균농도(minimum bacteriocidal concen- tration, $\mathrm{MBC}$ ) 측정}

최소발육억제농도 시험관을 포함한 육안으로 세균의 증 식이 보이지 않는 시험관에서 멸균된 백금이로 $1 \mathrm{loop}$ 를 따서 혈액우무배지에 접종한 후 $37^{\circ} \mathrm{C}$ 배양기에서 24 시간 배양 후 세균의 발육 여부를 관찰하였다.

\section{결 과 \\ 의료관련감염 항생제 내성 세균의 분리}

임상검체에서 분리된 세균 중 메티실린 내성 황색포 도알균(Methicillin-resistant Staphylococcus aureus, MRSA), 반코마이신 내성 장알균(vancomycin-resistant Enterococcus, $\mathrm{VRE}$ ), 카바페넴 분해효소 생성 폐렴 막대균(Klebsiella pneumoniae Carbapenemase Producing, $\mathrm{KPC}$ ), 다제 내성 녹 농균(multidrug-resistant Pseudomonas aeruginosa, MRPA) 등 의료관련 감염세균 4종을 분리하였다.

\section{소독제의 최소발육억제농도(minimum inhibitory concen- tration, MIC) 측정}

의료관련 다제내성 세균에 대한 소독제의 농도를 $100 \%$, $50 \%, 25 \%, 12.5 \%, 6.25 \%, 3.13 \%, 1.56 \%, 0.78 \%, 0.39 \%$, $0.18 \%$ 로 계열 희석하여 $37^{\circ} \mathrm{C}$ 배양기에서 24 시간 배양 후 육안으로 관찰한 결과 혼탁을 볼 수 없는 가장 낮은 시 험관의 농도를 최소발육억제농도(MIC)로 하여 소독제 농 도를 확인한 결과 대조 균주인 Escherichia coli ATCC 25922와 Methicillin resistant Staphylococcus aureus (MRSA) 는 Peracetic acid와 Sod. hypochlorite의 $0.18 \%$ 농도의 시험 관까지 증식이 없었으나, Phenol에서는 $1.6 \%$ 이하의 농도 에서 세균이 증식하였고, $3.1 \%$ 이상의 농도에서는 모두 세균이 증식하지 않아서 $\mathrm{Phenol}$ 의 $\mathrm{MIC}$ 는 $3.1 \%$ 로 판정 하였다. Vancomycin resistant Enterococcus faecium (VRE)은 Peracetic acid에서는 모든 농도의 용액에서 증식하지 않 았으나 Sod. hypochlorite 용액에서는 $0.8 \%$ 용액 이하의 농도에서 모두 증식하였으며, $1.6 \%$ 이상의 농도에서부터 모두 증식하지 않아 $1.6 \%$ 농도를 Sod. hypochlorite 용액 의 $\mathrm{MIC}$ 로 판정하였다. Phenol 용액에서는 $1.6 \%$ 용액 이 하의 농도에서 모두 증식하였으며, $3.2 \%$ 이상의 농도에 서부터는 모두 증식하지 않아 $3.2 \%$ 농도를 Phenol 용액 의 $\mathrm{MIC}$ 로 판정하였다. Carbapenemase Producing Klebsiella pneumoniae (KPC)과 Multi-drug resistance Pseudomonas aeruginosa (MRPA)에서는 Peracetic acid와 Sod. Hypochlorite 용액에서는 모든 농도에서 증식되지 않았지만 Phenol 용 액에서는 $3.1 \%$ 이하의 농도에서 모두 증식하였으며, $6.2 \%$ 이상의 농도에서부터는 모두 증식하지 않아 $6.2 \%$ 농도를 Phenol 용액의 MIC로 판정하였다(Table 1).

\section{소독제의 최소살균농도(minimum bactericidal concen- tration, $\mathrm{MBC}$ ) 측정}

의료관련 다제내성 세균에 대한 최소발육억제농도(MIC) 를 측정한 후 $\mathrm{MIC}$ 이상의 세균이 증식하지 않은 농도 의 시험관을 대상으로 혈액우무배지에 접종하여 항생제 가 들어 있지 않은 배지에서 자란 세균의 집락 수 대비 99.99\% 이상의 살균효과를 나타내는 농도를 $\mathrm{MBC}$ 로 정 하여 소독제 농도를 확인한 결과 대조 균주인 Escherichia coli ATCC 25922는 Peracetic acid에서 $\mathrm{MIC}$ 와 $\mathrm{MBC}$ 가 $0.18 \%$ 농도로 같은 농도를 보였으며, Sod. hypochlorite에서 는 $\mathrm{MIC}$ 는 $0.39 \%$ 를 보였고, $\mathrm{Phenol}$ 에서 $\mathrm{MIC}$ 와 $\mathrm{MBC}$ 는 모 두 $3.1 \%$ 를 보였다. Methicillin resistant Staphylococcus aureus 
Table 1. Minimum inhibitory concentration test of disinfectant for healthcare-associated multi-drug resistant from clinical isolates

\begin{tabular}{|c|c|c|c|c|c|c|c|c|c|c|c|c|c|c|c|c|c|c|c|c|}
\hline \multirow{2}{*}{$\begin{array}{l}\text { Disinfectant } \\
(\%)\end{array}$} & \multicolumn{4}{|c|}{$\begin{array}{l}\text { Escherichia coli } \\
\text { ATCC } 25922\end{array}$} & \multicolumn{4}{|c|}{ MRSA } & \multicolumn{4}{|c|}{ VRE } & \multicolumn{4}{|c|}{$\mathrm{KPC}$} & \multicolumn{4}{|c|}{ MRPA } \\
\hline & 6.2 & 3.1 & 1.6 & 0.8 & 6.2 & 3.1 & 1.6 & 0.8 & 6.2 & 3.1 & 1.6 & 0.8 & 6.2 & 3.1 & 1.6 & 0.8 & 6.2 & 3.1 & 1.6 & 0.8 \\
\hline $\begin{array}{l}\text { Peracetic } \\
\text { acid }\end{array}$ & $\mathrm{NG}$ & $\mathrm{NG}$ & NG & NG & $\mathrm{NG}$ & NG & NG & NG & $\mathrm{NG}$ & NG & NG & NG & NG & $\mathrm{NG}$ & $\mathrm{NG}$ & NG & NG & NG & $\mathrm{NG}$ & NG \\
\hline Phenol & $\mathrm{NG}$ & $\mathrm{NG}$ & $\mathrm{G}$ & $\mathrm{G}$ & $\mathrm{NG}$ & NG & $\mathrm{G}$ & $\mathrm{G}$ & $\mathrm{NG}$ & NG & $\mathrm{G}$ & G & NG & $\mathrm{G}$ & G & $\mathrm{G}$ & $\mathrm{NG}$ & $\mathrm{G}$ & $\mathrm{G}$ & G \\
\hline $\begin{array}{l}\text { Sod. } \\
\text { hypochlorite }\end{array}$ & NG & NG & NG & NG & NG & NG & NG & NG & NG & NG & NG & G & NG & NG & NG & NG & NG & NG & NG & NG \\
\hline
\end{tabular}

Abbreviation; NG: no growth, G; growth, MRSA; Methicillin resistant Staphylococcus aureus, VRE; Vancomycin resistant Enterococcus faecium, KPC; Klebsiella pneumoniae Carbapenemase Producing, MRPA; Multi-drug resistance Pseudomonas aeruginos

Table 2. Minimum inhibitory concentration and minimum bactericidal concentration of disinfectant for healthcare-associated multi-drug resistant from clinical isolates

\begin{tabular}{|c|c|c|c|c|c|c|}
\hline \multirow{2}{*}{ Microorganisms } & \multicolumn{2}{|c|}{ Peracetic acid (\%) } & \multicolumn{2}{|c|}{ Phenol (\%) } & \multicolumn{2}{|c|}{ Sodium hypochlorite (\%) } \\
\hline & MIC & MBC & MIC & $\mathrm{MBC}$ & MIC & $\mathrm{MBC}$ \\
\hline Escherichia coli ATCC 25922 Control & 0.18 & 0.18 & 3.1 & 3.1 & 0.18 & 0.36 \\
\hline $\begin{array}{l}\text { Methicillin resistant } \\
\text { Staphylococcus aureus (MRSA) }\end{array}$ & 0.18 & 0.18 & 3.1 & 3.1 & 0.39 & 0.78 \\
\hline $\begin{array}{l}\text { Vancomycin resistant } \\
\text { Enterococcus faecium (VRE) }\end{array}$ & 0.18 & 0.18 & 3.1 & 3.1 & 0.78 & 0.78 \\
\hline $\begin{array}{l}\text { Klebsiella pneumoniae } \\
\text { Carbapenemase Producing (KPC) }\end{array}$ & 0.18 & 0.18 & 6.2 & 6.2 & 0.39 & 0.78 \\
\hline $\begin{array}{l}\text { Multi-drug resistant } \\
\text { Pseudomonas aeruginosa (MRPA) }\end{array}$ & 0.18 & 0.18 & 6.2 & 6.2 & 0.39 & 0.78 \\
\hline
\end{tabular}

Abbreviation; MIC; minimum inhibitory concentration

$\mathrm{MBC} ;$ minimum bactericidal concentration

(MRSA)는 Peracetic acid에서 $\mathrm{MIC}$ 와 $\mathrm{MBC}$ 가 $0.18 \%$ 농도 로 같은 농도를 보였고, Sod. hypochlorite에서는 $\mathrm{MIC}$ 는 $0.39 \%$ 를 보였고, $\mathrm{MBC}$ 는 $0.78 \%$ 를 보였으며, Phenol에서 $\mathrm{MIC}$ 와 $\mathrm{MBC}$ 는 모두 $3.1 \%$ 를 보였다.

Vancomycin resistant Enterococcus faecium (VRE)은 Peracetic acid에서는 $\mathrm{MIC}$ 와 $\mathrm{MBC}$ 가 $0.18 \%$ 농도로 같은 농도 를 보였으며, Sod. hypochlorite에서는 $\mathrm{MIC}$ 와 $\mathrm{MBC}$ 는 모두 $0.78 \%$ 를 보였다.

Phenol에서 $\mathrm{MIC}$ 와 $\mathrm{MBC}$ 는 모두에서 $3.1 \%$ 를 보였다. Carbapenemase Producing Klebsiella pneumoniae (KPC)와 Multi-drug resistance Pseudomonas aeruginosa (MRPA)에서 는 모두 Peracetic acid에서는 $\mathrm{MIC}$ 와 $\mathrm{MBC}$ 가 $0.18 \%$ 농도 로 같은 농도를 보였으며, Sod. hypochlorite에서는 $\mathrm{MIC}$ 는 $0.39 \%, \mathrm{MBC}$ 는 $0.78 \%$ 를 보였다. Phenol에서 $\mathrm{MIC}$ 와 $\mathrm{MBC}$ 는 모두 $6.2 \%$ 를 보였다(Table 2).

\section{고 찰}

의료환경에서의 소독은 병원성 또는 잠재적 병원성 미 생물로 인한 감염증을 예방하거나 감소시키는 것을 목표 로 한다. 의료환경 표면의 오염은 공중보건학적으로 매우 중요한 문제가 되고 있다(Quinn et al., 2015). 특히 의료관 련 감염 다제 내성균들은 병원의 세면기구, 화장실, 청소 도구, 금속 파이프 및 바닥 배수구 등에서 자라며 불리한 조건으로부터 균체를 보호하기 위해 생물막을 만들 수 있다. 다양한 항균물질에 대한 내성은 환자의 치료 방법 을 변화시킬 수 있으며, 의료환경에서 소독방법을 개선할 필요성이 증가하고 있다(Al-Tawfiq and Tambyah, 2014)

따라서 과초산은 이와 같은 단점이 없기 때문에 의료 장비의 세척에 사용되기 시작하였으며, FDA는 Steris 20 Sterilant를 내시경, 관절경 및 기타 외과용 기구를 위한 자동화된 액체 화학 살균처리 장치인 Steris System 1과 함께 사용하도록 승인하였다. 특히 의료기기, 내시경 및 
혈액 투석기의 소독제로 과거에 사용되던 전통적인 소독 제를 대체하여 사용하고 있다. 차아염소산나트륨은 강력 한 산화제이며 인화성 물질 및 인덕터와 반응하지만 차 아염소산나트륨 용액은 인화성이 약한 염기이다. 차아염 소산 나트륨은 운반과 보관에 안전하며, 소독 효과는 염 소 가스만큼 효과적이다. 일반적으로 3 5\% 수용액을 소 독제로 사용하지만 아포(spore)를 가지는 세균에는 살균 력을 가지지 못하는 한계가 있다(Maria et al., 2018).

이 연구에 사용한 소독제 중 Phenol에 대한 소독력 을 측정한 결과 Methicillin resistant Staphylococcus aureus (MRSA)와 Vancomycin resistant Enterococcus faecium (VRE) 은 $1.6 \%$ 이하의 농도에서 세균이 증식하였고, $3.1 \%$ 이 상의 농도에서는 모두 세균이 증식하지 않아서 $\mathrm{MIC}$ 와 $\mathrm{MBC}$ 는 모두 $3.1 \%$ 를 보였으며, Klebsiella pneumoniae Carbapenemase Producing (KPC)과 Multi-drug resistance Pseudomonas aeruginosa (MRPA)에서는 $3.1 \%$ 이하의 농도 에서 모두 증식하였고, $6.2 \%$ 이상의 농도에서부터는 모 두 증식하지 않아 $\mathrm{MIC}$ 와 $\mathrm{MBC}$ 는 모두 $6.2 \%$ 를 보였다. 이는 1:100으로 희석한 phenol 용액에서 실험에 사용한 Staphylococcus aureus 20개 균주 모두 사멸했지만 Pseudomonas aeruginosa의 경우 20 개 균주 중 3 균주가 생존하 여 그람음성세균에 phenol의 활성이 부족하다는 결과와 비슷한 결과를 나타냈다(Maria et al., 2018). 이번 실험에 사용한 페놀은 일반적인 세균에 대한 살균 및 결핵균에 활성이 높은 것으로 알려져 있으며, 고농도에서 세포벽을 통과하여 세포질에 독작용을 일으켜 세포 단백질을 침전 시키는 작용을 하고, 저농도 및 고 분자량 페놀 유도체는 필수 효소 시스템의 불활성화 및 세포벽에서 필수 대사 물질을 누출하여 세균의 사멸을 유발하는 것으로 알려졌 다(Goddard and McCue, 2001).

Peracetic acid (PAA)에 대한 소독력을 측정한 결과 $\mathrm{MRSA}$ 와 $\mathrm{VRE}, \mathrm{KPC}$ 및 $\mathrm{MRPA}$ 에서는 모든 농도에서 증 식되지 않아 $\mathrm{MIC}$ 와 $\mathrm{MBC}$ 는 모두 $0.18 \%$ 를 보여 가장 강 한 살균력을 보였다. 과초산 기반 소독제는 식품 산업과 물 또는 하수처리 회사에서 사용되며, 열 감응 의료 장비 및 병원에서 사용하는 내시경 등 장비의 오염 제거 및 멸균에도 빠르게 작용하며, 세균, 곰팡이, 바이러스 및 포자에 효과적으로 작용하는 것으로 알려졌다(Chino et al., 2017).

본 연구에서 Sodium hypochlorite $(\mathrm{NaOCl})$ 용액에서 $\mathrm{MRSA}$ 의 $\mathrm{MIC}$ 는 $0.39 \%$ 를 보였고, $\mathrm{MBC}$ 는 $0.78 \%$ 를 보였 으며, $\mathrm{VRE}$ 는 $\mathrm{MIC}$ 와 $\mathrm{MBC}$ 는 모두 $0.78 \%$ 를 보였다. $\mathrm{KPC}$
와 $\mathrm{MRPA}$ 는 각각 $\mathrm{MIC}$ 는 $0.39 \%, \mathrm{MBC}$ 는 $0.78 \%$ 를 보였다. $\mathrm{NaOCl}$ 용액은 잘 알려진 항균작용과 조직용해 능력으로 인해 70 년 이상 사용되어 왔지만 $0.5 \%$ 내지 $5.25 \%$ 범위 내의 최적 농도에 대한 일반적인 합의는 존재하지 않는 것으로 알려져 있으며, Siqueira et al. 의 연구에서는 치아 근관 실험에서 $0.5 \%$ 내지 $5 \%$ 범위의 $\mathrm{NaOCl}$ 농도 사이 에 항균효과의 유의한 차이를 나타내지 않았다는 보고도 있다(Siqueira et al., 2000).

Berber et al.의 연구에서는 치아 세관에 대한 시험농도 사이에 통계적으로 유의한 차이가 있었다는 보고도 있 어 병원환경 소독에서 균종별, 농도별, 여러 가지 조건 에서 좀 더 다양한 연구가 되어야 할 것으로 생각된다 (Berber et al., 2006).

실험에 사용된 모든 의료관련 다제내성 균주에 대해 차아염소산 나트륨과 과초산은 모두 강한 살균력이 있었 지만 페놀에 대해서는 그람양성세균에서는 강한 살균력 을 그람음성세균에서 약한 살균력을 가지고 있어 임상 분리 균주에 대한 항생제 내성과 소독제의 살균력 사이 의 상관관계를 발견하지 못했다. Rutala et al.의 연구에서 임상분리 균주에 대한 항생제에 대한 내성과 소독제의 살균력 사이의 명백한 상관관계를 발견하지 못했다는 보 고와 우리의 연구와는 일치된 결과를 보였다(Rutala et al., 1997).

의료관련 다제내성 세균 감염이 증가하고, 의료환경에 서의 감염관리를 위한 소독과 오염제거를 위한 소독제의 선택이 어느 때보다 중요한 상황에서 의료관련 감염 다 제내성 세균에 대한 소독제의 효능 실험을 시도했다는데 의미가 있는 것으로 생각된다.

\section{ACKNOWLEDGEMENT}

None.

\section{CONFLICT OF INTEREST}

No potential conflict of interest relevant to this article was reported.

\section{REFERENCES}

Al-Tawfiq JA, Tambyah PA. Healthcare associated infections (HAI) perspectives. J Infect Public Health. 2014. 7: 339-344. Berber VB, Gomes FA, Sena NT, et al. Reduction of E. faecalis by $\mathrm{NaOCl}$ and different instrumentation techniques. International 
Endodontic Journal. 2006. 39: 10-17.

Chino TY, Nukui T, Morishita Y, et al. Morphological bactericidal fast-acting effects of peracetic acid, a high-level disinfectant, against Staphylococcus aureus and Pseudomonas aeruginosa biofilms in tubing. Antimicrobial Resistance and Infection Control. 2017. 6: 122.

Chung DR. Transmission and Prevention of Healthcare-Associated Infections. Korean J Med. 2018. 93: 317-323.

Goddard PA, McCue KA. Phenolic compounds. In Disinfection, Sterilization, and Preservation, 5th ed.; Block, S.S., Ed.; Lippincott Williams \& Wilkins: Philadelphia, PA, USA, 2001. pp: 255-281.

Guimarães MA, Anita T, Nunes MP, et al. Disinfectant and antibiotic activities: a comparative analysis in brazilian hospital bacterial isolates. Brazilian Journal of Microbiology. 2000. 31: 193-199.

Lee MJ, Kim YS, et al. Evaluation of Efficacy of Sanitizers and Disinfectants Marketed in Korea. Korean Journal of Food Science and Rechnology. 2005. 8: 671-677.

Malchesky PS. Peracetic acid and its application to medical instrument sterilization. Artif. 1993. 17: 147-152.

Maria M, Małgorzata K, Robert D, et al. Review Phenolic Compounds Diminish Antibiotic Resistance of Staphylococcus aureus Clinical Strains Int. J Environ Res Public Health. 2018.
15: $1-18$

Quinn MM, Henneberger PK, Braun B, et al. National Institute for Occupational Safety and Health (NIOSH); National occupational research agenda (NORA) cleaning and disinfecting in healthcare working group; et al. Cleaning and disinfecting environmental surfaces in health care: Toward an integrated framework for infection and occupational illness prevention. Am. J. Infect. Control 2015. 43: 424-434.

Rutala WA, Stiegel MM, Sarubbi FA, Weber DJ. Susceptibility of antibiotic-susceptible and antibiotic-resistant hospital bacteria to disinfectants. Infect Control Hosp Epidemiol. 1997. 18: 417-421.

Siqueira JF, Rôças IN, Favieri A, Lima KC. Chemomechanical reduction of the bacterial population in the root canal after instrumentation and irrigation with $1 \%, 2.5 \%$ and $5.25 \%$ of hypochlorite. Journal of Endodontics. 2000. 26: 331-334

https://doi.org/10.15616/BSL.2021.27.4.264

Cite this article as: $\mathrm{An} \mathrm{JL}, \mathrm{Kim} \mathrm{SH}, \mathrm{Yu} \mathrm{YB}, \mathrm{Kim} \mathrm{S}$, Lee MS, Kim YK. Efficacy of Disinfectants against Health-Associated Multi-drug Resistant Clinical Isolates. Biomedical Science Letters. 2021. 27: 264-269. 